

UNIVERSITY OF CALIFORNIA

Division of Agriculture and Natural Resources http://anrcatalog.ucdavis.edu

\title{
FOREST STEWARDSHIP SERIES 9: Forest Streams
}

\author{
SUSAN D. KOCHER, UCCE Natural Resources Advisor, El Dorado County; RICHARD \\ HARRIS, UCCE Forestry Specialist, Department of Environmental Science, Policy, and \\ Management, University of California, Berkeley
}

Stream channels add diversity, beauty, and excitement to forested property. Streams and the riparian vegetation associated with them also supply important habitat for many species of aquatic and terrestrial wildlife (fig. 1). In order to preserve these important functions and maintain healthy streams, it is important to first understand the role of stream channels in the landscape and how streams change over time.

\section{Objective}

Understand the role of streams, creeks, and rivers in the landscape in order to maintain them in healthy conditions on forested property.

\section{Competencies}

- Understand how current stream channel conditions reflect watershed inputs of sediment, water, and woody debris as well as human disturbance.

- Know how human uses and activities can affect stream channels.

- Learn that streams can be protected and restored to ecologically functional levels by managing inputs of sediment, water, and woody debris and by maintaining riparian vegetation.

\section{Related Forest Stewardship Series Publications}

- Riparian Vegetation, ANR Publication 8240

- Forest Water Quality, ANR Publication 8241

- Laws and Regulations Affecting Forests, Part I: Timber Harvesting, ANR Publication 8249

- Laws and Regulations Affecting Forests, Part Il: Activities Other Than Timber Harvesting, ANR Publication 8250

- Fish and Fish Habitat, ANR Publication 8242

- Forest Roads, ANR Publication 8247

- Technical and Financial Assistance, ANR Publication 8253

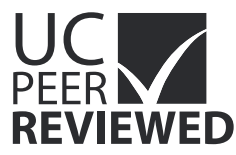

Figure 1. A healthy stream, such as the one shown here, has diverse instream habitat that usually consists of alternating fast water (riffles) and slow-moving deeper pools. Cover is provided by boulders, overhanging vegetation, and large wood. Riparian vegetation is continuous and dense and water quality is good. Photo: Richard Harris.

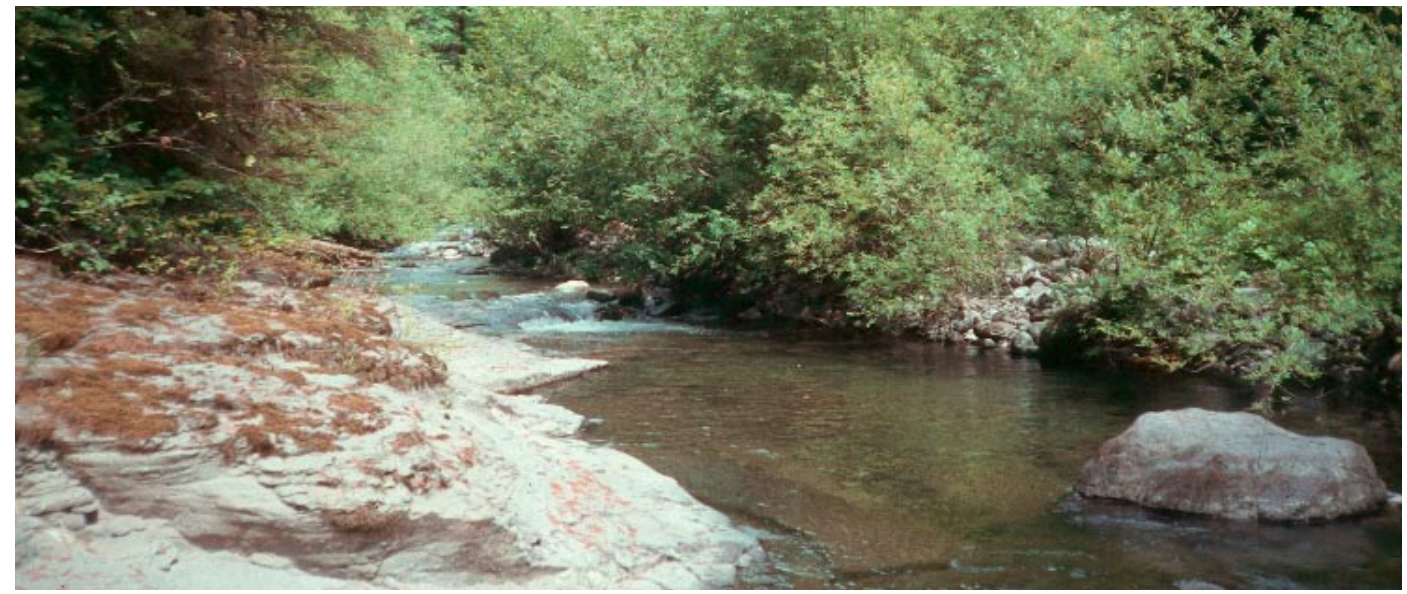

\section{THE ROLE OF STREAMS IN THE LANDSCAPE}

Natural streams are formed over a geologic time scale of thousands of years. Their main function is to move water, sediment, and woody debris from higher to lower points in watersheds, often over long distances.

At the watershed level, streams or parts of streams are often divided by function into source, transport, and response areas, or reaches. Source areas are the steep upper-elevation locations where sediment is produced (fig. 2). Transport areas are the parts of a stream system where sediment and water move from higher to lower elevations. Response reaches are places where sediment and other products collect in the watershed. 
Stream functions are in part determined by whether streams flow year-round (perennial), go dry for part of the year (intermittent), or flow only during periods of rainfall or snowmelt (ephemeral). Generally, ephemeral and intermittent streams are located in source areas or serve a transport function. Perennial streams may have all three functions-source, transport, and response. Although perennial streams clearly have the greatest potential to support wildlife and aquatic life, the linkages among streams of all types means that healthy habitat depends on healthy streams throughout the watershed.

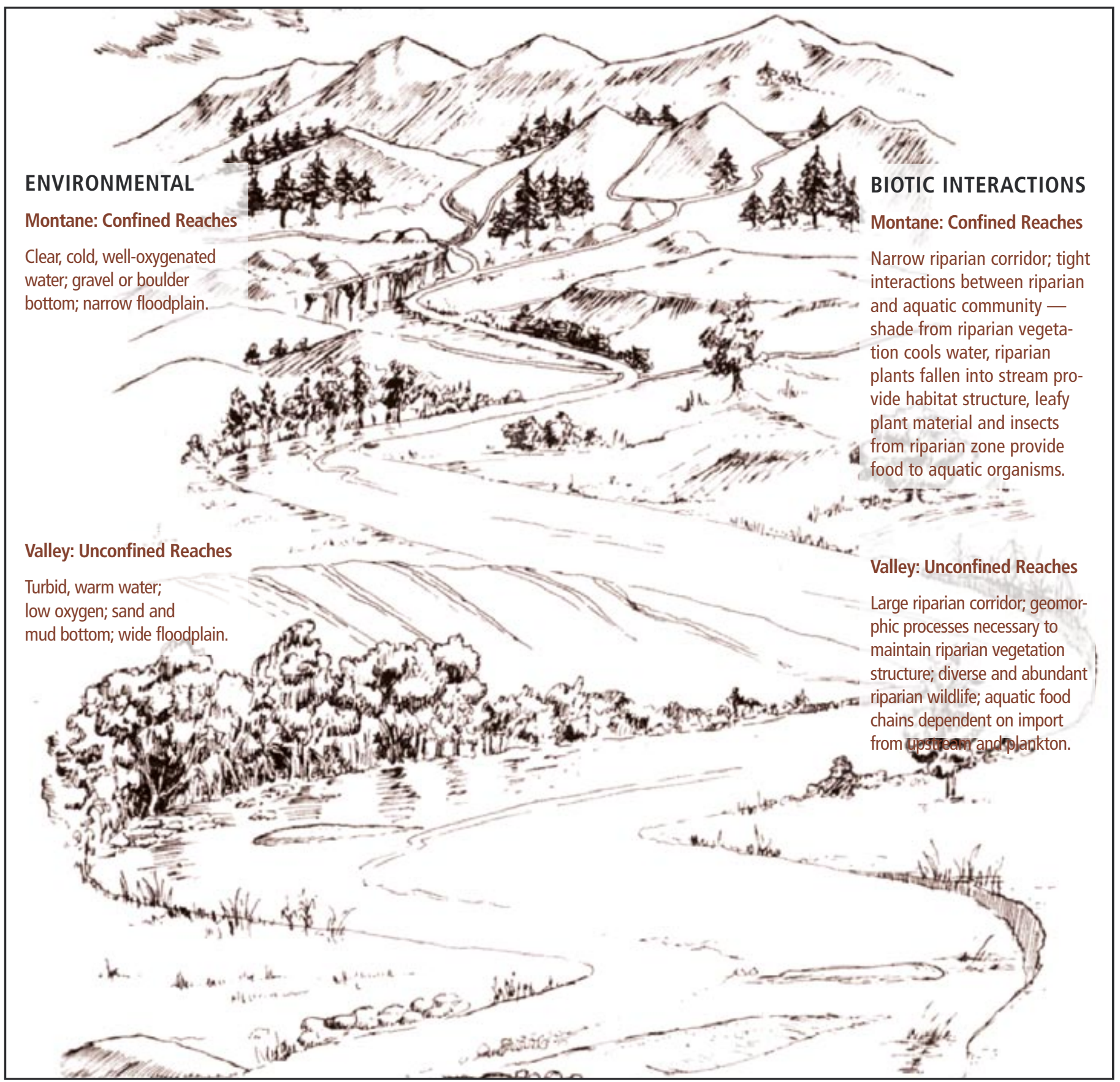

Figure 2. Variation in stream ecosystems from mountainous to valley portions of a watershed. Upper parts of watersheds tend to have simple communities and cold-water fishes like trout. Lower watershed areas tend to have complex communities and warm-water fishes. Source: Redrawn from California's Rivers: A Public Trust Report (Sacramento: California State Lands Commission, 1993), p. 230. 


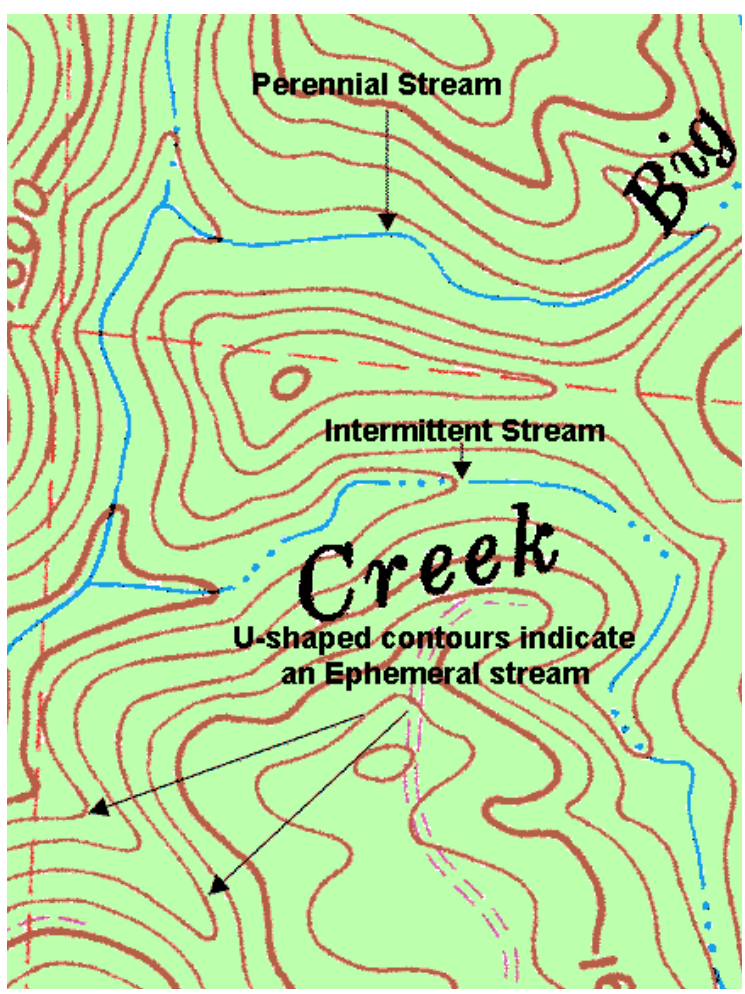

Figure 3. On topographic maps, streams are often depicted as solid blue lines if they are perennial or dashed blue lines if they are intermittent. Ephemeral streams may not be indicated at all and can be located only by careful inspection of contour lines on maps.

\section{STREAM CLASSIFICATION}

Streams are described in many ways. On topographic maps, they are often depicted as solid blue lines to indicate they are perennial or dashed blue lines if they are intermittent (fig. 3). Ephemeral streams may not be indicated on a contour map at all; as a general rule, topographic maps do not show the majority of the streams on a property, because most streams are ephemeral. Careful examination of the contour lines on a map can indicate where ephemeral streams may be, yet when seen in the field, they may barely be evident. Nevertheless, ephemeral streams are important for delivering sediment and wood to lower watershed reaches.

Streams can be classified in other ways besides flow regime. Several classification systems are used in California. Some systems distinguish streams by physical characteristics such as channel slope, channel width, and stream bed substrate. People involved in scientific investigations or stream restoration planning commonly use these systems. Other systems are based on regulatory requirements. In California, several agencies use a system that classifies streams on the basis of flow, presence of aquatic life, and uses. The resulting classes are used to prescribe protection during activities such as timber harvesting.

A landowner may find scientific classification to be a useful tool for management planning. Stream classification can be used to determine existing conditions relative to a natural, undisturbed state; for prescribing restoration needs; and for evaluating sensitivities to uses. If your property contains perennial streams, there is a high likelihood that the stream has been classified, and often, the aquatic habitat on perennial streams has been classified as well. You can find out whether and how your streams have been classified by contacting your local California Department of Fish and Game (DFG) office.

\section{THE STREAM AND ITS FLOODPLAIN}

In cross-section, a stream may include one or more channels that convey flow and one or more adjacent deposits (fig. 4). These adjacent deposits are known as the floodplain, an area that is inundated by water when the capacity of the stream channel is exceeded. Not all streams have floodplains. For example, streams at high elevations may be steep and narrow and incised in bedrock with no floodplain at all. To have a floodplain, a stream must have sufficient available materials (sand, silt, gravel) and flow. Consequently, streams with extensive floodplains are mainly found at lower elevations.

A stream builds a floodplains as it erodes its bed and banks and deposits the material elsewhere. The classic example of floodplain building is the point bar on a meander bend where the stream erodes one side of the channel and deposits the material on the opposite side (fig. 5).

The capacity of a stream channel is referred to as its bankful discharge, the maximum volume of water a channel can carry before it overtops its banks and inundates its floodplain. The position of the bankful discharge in a stream channel can often be determined in the field using physical indicators such as breaks in slope, drift lines, 
Figure 4. Cross-section of a floodplain indicating the lowflow channel (LF), floodplain or floodway (FP), 100-year flood level (dashed line) and 100-year floodplain (FP 100).

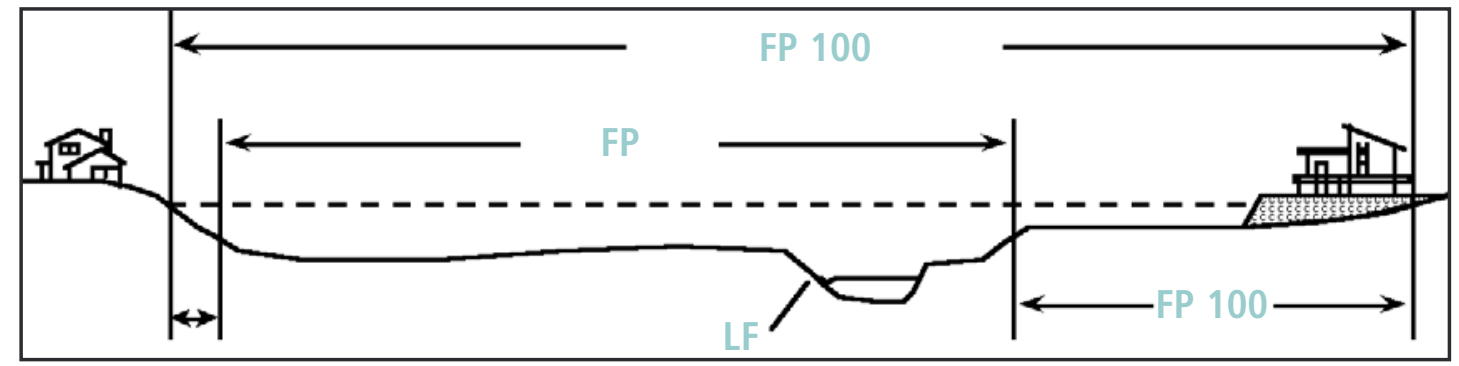

and changes in soils or vegetation. The current shape of a channel is largely a reflection of the "work" (erosion and deposition) done by the bankful discharge. When discharges exceed channel capacity, steeper streams without floodplains often undercut steep upland slopes, sometimes triggering landslides.

Because streams and their associated floodplains are exceptionally sensitive to land use impacts, they are the focus of many regulations affecting forest uses. All perennial streams, with or without floodplains, may support fish and other aquatic life. Changes in watershed conditions such as fire, timber harvesting, or road construction may directly or indirectly affect streams.

\section{STREAM CHANNEL COMPLEXITY}

Fish and other aquatic organisms have evolved to thrive in stream channels with particular sediment, water, and debris loads, as well as particular channel shapes and bedforms. In general, more complex channels with a variety of pools (slow water) and riffles (fast water) provide the best aquatic and cold-water fish habitat. Channels at higher elevations may have a stepped profile, with rock outcrops creating deep pools. At middle elevations, streams may have steps formed by rock or accumulations of large wood that create a

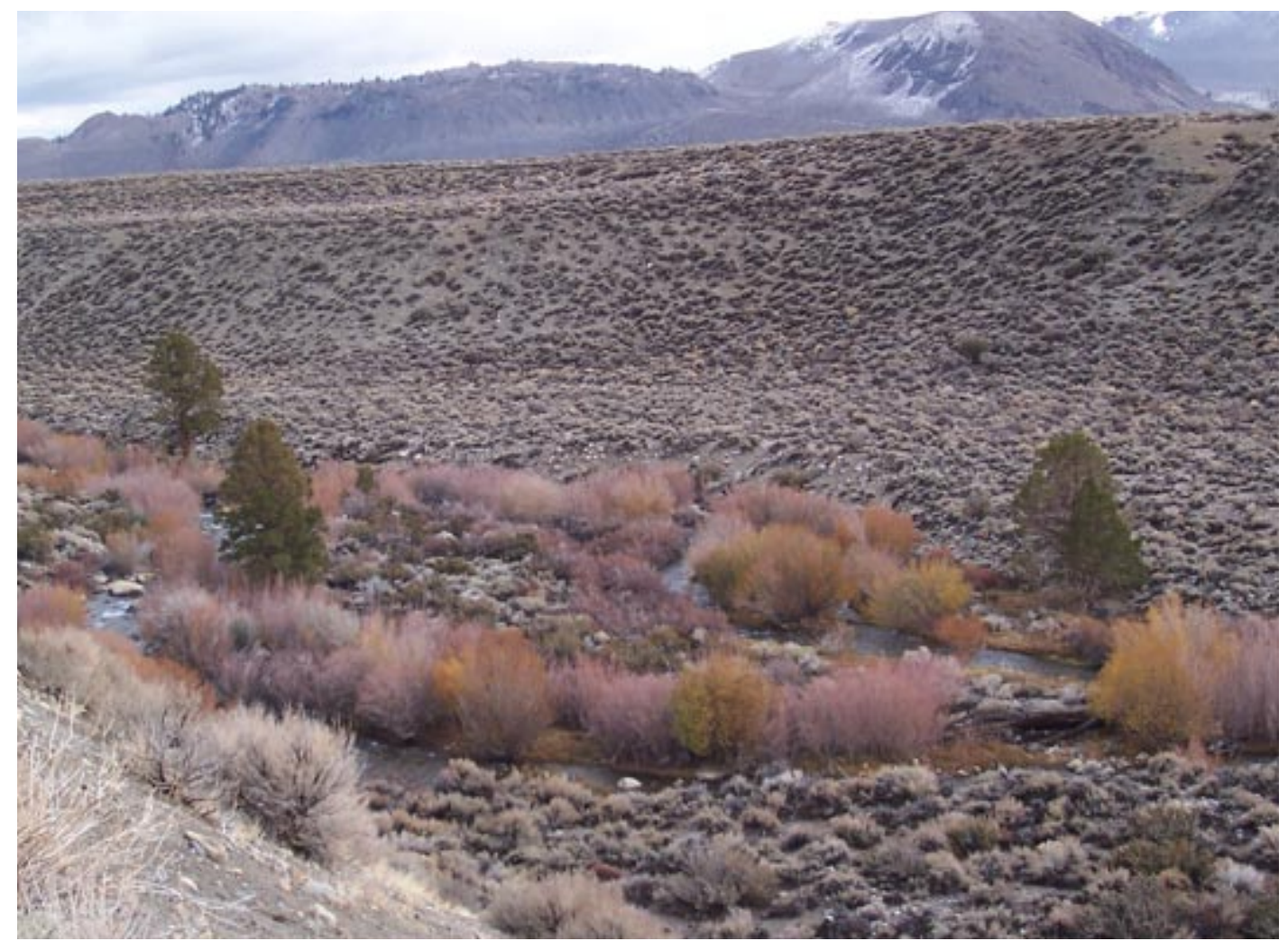

Figure 5. Rush Creek, Mono Basin, Inyo County. The breadth of the floodplain extends between the two steep slopes. The channel braids and meanders across the floodplain over the course of time. The entire flooplain is subject to inundation during a large flood. Photo: Richard Harris. 
Figure 6. Although this forest stream may look damaged and unhealthy, large woody debris plays important roles by stabilizing channels, creating habitat for fish and invertebrates, and storing sediment. Photo: Richard Harris. diversity of pools (fig. 6). At lower elevations, pools tend to form in locations scoured by concentrated flows at meander bends. Structural controls such as wood accumulations and rock tend to be less prominent in larger, low-elevation streams.

\section{FISH HABITAT FEATURES}

Not all landowners have streams that support fish, but even ephemeral streams may support amphibians such as salamanders and frogs. Some of these creatures are protected under state and federal endangered species acts. Consult with your local DFG office to determine whether streams or other wetlands on your property may support amphibians.

Stream characteristics important for fish include physical features such as pools and riffles, bed substrate, and riparian vegetation. Rocks and large pieces of wood create pools and riffles and provide cover for fish. In riffles where the surface flow is turbulent, the flowing water delivers insects for food, provides cover from predators, and allows the water oxygen content to be replenished.

Plunge pools are formed where water falls over a boulder or log, scouring a deep hole. Logs, root wads, boulders, and stream banks can cause backwater pools to form as water swirls around the obstacle. Juvenile and adult fish often hide in both plunge and backwater pools.

The quality and size of bed substrate may determine whether fish can spawn at a particular location. For example, trout and salmon require clean gravel substrate for nesting. If the bed substrate is too large or has an overabundance of sand and silt, spawning may be unsuccessful.

The vegetation on, near, and overhanging the water, known as riparian vegetation, provides plant materials that are consumed by aquatic animals and also provides shade that helps keep streams cool during the summer.

\section{THE EFFECTS OF HUMAN DISTURBANCE ON STREAMS}

Human disturbance that changes the amount of water, sediment, or woody debris in a channel or removes riparian vegetation will most likely make channels chronically unstable, impair water quality with sediment, or reduce channel complexity-all of which degrade fish habitat (table 1).

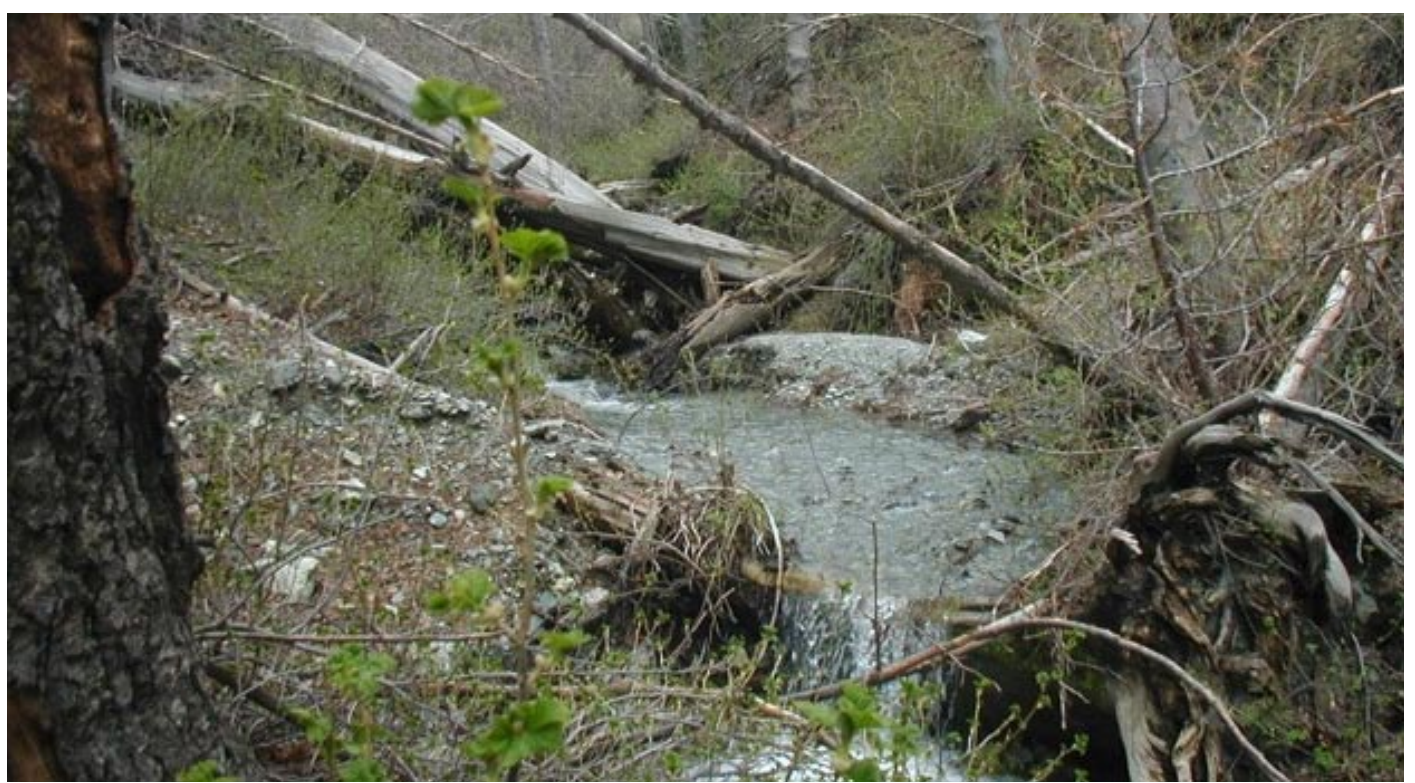


Table 1. Channel modifications and impacts on fish habitat

\begin{tabular}{|l|l|l|}
\hline Modification & Impact \\
\hline dams or other diversion structures & migration barriers, loss of spawning and rearing habitat \\
\hline reservoirs or other impoundments & altered flows, loss of downstream sediment discharge \\
\hline levees and dikes for flood control & loss of side channels and floodplain function, decreased channel length, reduced habitat complexity \\
\hline channel straightening, hardening, or relocation & loss of habitat features such as pools and sources of spawning gravel \\
\hline dredging & reduced habitat complexity, disruption of bottom substrate \\
\hline stream bank protection (rip-rap) & reduced pool scouring, potential for downstream erosion \\
\hline roads next to streams & loss of side channels, impacts on riparian vegetation and water quality \\
\hline road crossings (e.g., culverts) & migration barriers, reduced habitat complexity, potential for downstream erosion \\
\hline sand and gravel mining & potential for sedimentation or erosion, reduced habitat complexity \\
\hline
\end{tabular}

For example, dams and artificial impoundments slow stream flow and cause heavier sediment particles, such as gravels, to settle out above the dam. As a result, channels below the dam will have less gravel than in a natural system, reducing the quality of habitat for fish spawning.

Roads constructed next to streams can act as dikes or levees that cut off the stream from its floodplain and confine floodwaters to the channel. Since the water cannot disperse over a floodplain, it speeds up, gathers power, and erodes banks downstream from the road. Road construction in upper watershed areas near intermittent and ephemeral streams can cause downstream impacts. Roads can also deliver sediment to streams and change drainage patterns. In effect, a road system can act as an artificial extension of the natural drainage system. These effects move through the system from upper to lower watershed areas, eventually affecting perennial streams.

\section{Avoiding Channel Impacts}

The best way to avoid impacting streams is to avoid changing them from their natural state.

- Keep heavy equipment out of streams.

- Minimize road construction in riparian areas.

- Minimize road crossings over perennial and intermittent watercourses.

- Look for alternatives to relocating or straightening stream channels by redesigning construction projects.

- Consider alternatives to conventional culverts for stream crossings.

- Avoid installing riprap on stream banks, since this may cause downstream erosion.

Removal of riparian vegetation weakens stream banks, allowing them to erode more easily during floods. These stream channels may migrate at an excessive rate or erode adjacent upland slopes, both of which cause excessive sedimentation that can reduce the quality of fish habitat by filling pools and gravel beds with fine sediment. 


\section{PERMITS REQUIRED FOR CHANNEL MODIFICATIONS}

The regulatory controls affecting streams are complex and vary according to the type of stream and the activities proposed. A landowner anticipating activities that would affect any stream is advised to consult with the local DFG office to determine whether permits are required. Generally, four agencies have regulatory control over perennial, intermittent, and ephemeral streams.

- DFG regulates activities that may affect instream life or habitat.

- The California Department of Forestry and Fire Protection (CAL FIRE) regulates timber management activities that may affect any type of stream.

- The Regional Water Quality Control Boards (RWQCBs) regulate activities that may affect water quality or quantity.

- The U.S. Army Corps of Engineers (USACE) regulates activities that may affect wetland or riparian conditions or waterway navigability.

- The National Marine Fisheries Service (NMFS) or the U.S. Fish and Wildlife Service (FWS) may also have jurisdiction on streams that support (or could support) threatened or endangered fish species.

Landowners wishing to carry out projects such as road building and culvert installation in active stream channels may be required to obtain a Streambed Alteration Agreement (known as a "1603 permit") from the CDFG and a permit from the USACE (known as a "404 permit"). Cities and counties may have their own permitting requirements if the road is intended for residential or public uses. Each agency typically requires mitigation measures to reduce the impact of a project on the channel, associated fish and wildlife habitat, and water quality.

CAL FIRE enforces the California Forest Practice Act and its implementation rules. Commercial timber harvesting requires a permit from CAL FIRE Many of these rules protect streams and associated riparian vegetation and include requirements for riparian buffer strips, prohibitions on allowing sediment or logging slash from entering streams, and standards for construction of logging roads. CAL FIRE's regulatory process includes participation by other agencies such as the DFG and RWQCB to ensure that their concerns are addressed.

The RWQCBs require permits for discharges of foreign materials into perennial streams. They also enforce water quality standards for beneficial uses in watercourses.

\section{MAINTAINING HEALTHY STREAMS}

The way to keep streams healthy is to maintain or restore the natural level of water, sediment, and woody debris in the channel and to maintain associated riparian vegetation.

\section{Management Techniques}

\section{Sediment}

- Proper planning of earth-moving operations can reduce sedimentation.

- Confine earth moving to dry months and use erosion and sediment control measures during rainy months.

- Retain vegetation buffers near work areas to filter out sediment.

- Install roads well away from streams and adjust drainage structures to get the water off the road as quickly as possible.

- Any water that carries sediment should be drained into vegetative filters.

- Properly size and align culverts to reduce risk of failure; install "fail-safe" culverts wherever possible. 


\section{Woody debris}

- Limit the removal of large wood from streams and floodplains to the amount absolutely necessary for protecting structures.

- Carefully plan harvests from riparian forests to ensure an adequate supply of large woody debris.

- Consider planting and managing for conifers where appropriate and possible in order to increase woody debris available to the stream in the future.

\section{Riparian vegetation}

- Maintain buffers of riparian vegetation along stream banks that are protected from human disturbance.

- Restrict forest management activities such as road construction or harvesting in this buffer area to minimize changes in stream channels.

\section{Water}

Changes in the runoff from your property can affect stream channels. Installing roads and culverts and removing vegetation often trigger these changes. Roads and commonly used in-slope drainage ditches interrupt the runoff of water from hillsides and bring it to streams more quickly. Culverts installed in streams redirect flow and may cause erosion when improperly sized and installed. Removal of upland vegetation allows more water to reach streams rather than being taken up by plants.

\section{Sediment}

Earth-moving operations on your property may increase sediment input to streams and affect their condition. Road construction and improperly conducted timber harvest can deliver excess sediment to streams. Locating gravel or dirt roads too close to streams also creates a source of chronic sediment input. Undersized or improperly aligned culverts may fail during storms and deliver sediment to streams while damaging the road as well.

\section{Woody Debris}

In the past, clearing or harvesting forests along streams removed sources of large woody debris that would fall into channels. California's current forest practice rules specify retention requirements for large woody debris. Clearing the stream channels in order to "improve" streams or protect roads and bridges deprives the stream of its natural inputs and can change habitat values.

\section{Vegetation}

Removing riparian vegetation weakens stream banks, allowing erosion during floods. Stream channels may then migrate excessively, erode their beds, and dewater surrounding lands. This degrades both fish habitat and water quality. Loss of shade can increase stream temperature during the summer months when fish and other aquatic life are vulnerable to heat stress.

\section{IMPROVING AND RESTORING STREAMS}

In some cases, maintaining the natural balance of stream inputs on your property may not be enough to protect your streams. Some streams may already be suffering from human-induced impacts throughout the watershed. They may be degraded to the point that they cannot become healthy without active management efforts. The degradation could be a consequence of past management on your property or the result of actions elsewhere in the watershed, since water, sediment, and woody debris come from the 
Figure 7. Large wood is often placed in streams as a means of restoring habitat for fish, as has been done at this site on the Gualala River in Mendocino County. The logs are marked to allow their location and movement to be monitored. Photo: Gary Nakamura. entire watershed upstream from your location. In order to maintain stream health at one location, all lands upstream must be considered. Stream and watershed protection is by definition a broad-scale effort.

\section{Working Cooperatively}

Cooperative stream and watershed protection efforts have increased over the last few years. Landowners have formed watershed councils or organizations to work on stream protection as groups. Some RCDs work with associations of landowners on large-scale conservation problems, and the RCDs may be involved in coordinating landowners for stream protection. Contact your local RCD or University of California Cooperative Extension office for more information on cooperative conservation efforts in your area.

Watershed and stream restoration projects are active measures taken to improve streams and return them to a healthier, more natural state. Restoration projects can be quite diverse, seeking to change land use, improve channel conditions, reduce sediment input, or increase riparian vegetation or large woody debris (fig. 7). Projects such as planting riparian vegetation, upgrading roads, and revegetating upslope areas can be quite successful in improving local stream or watershed conditions.

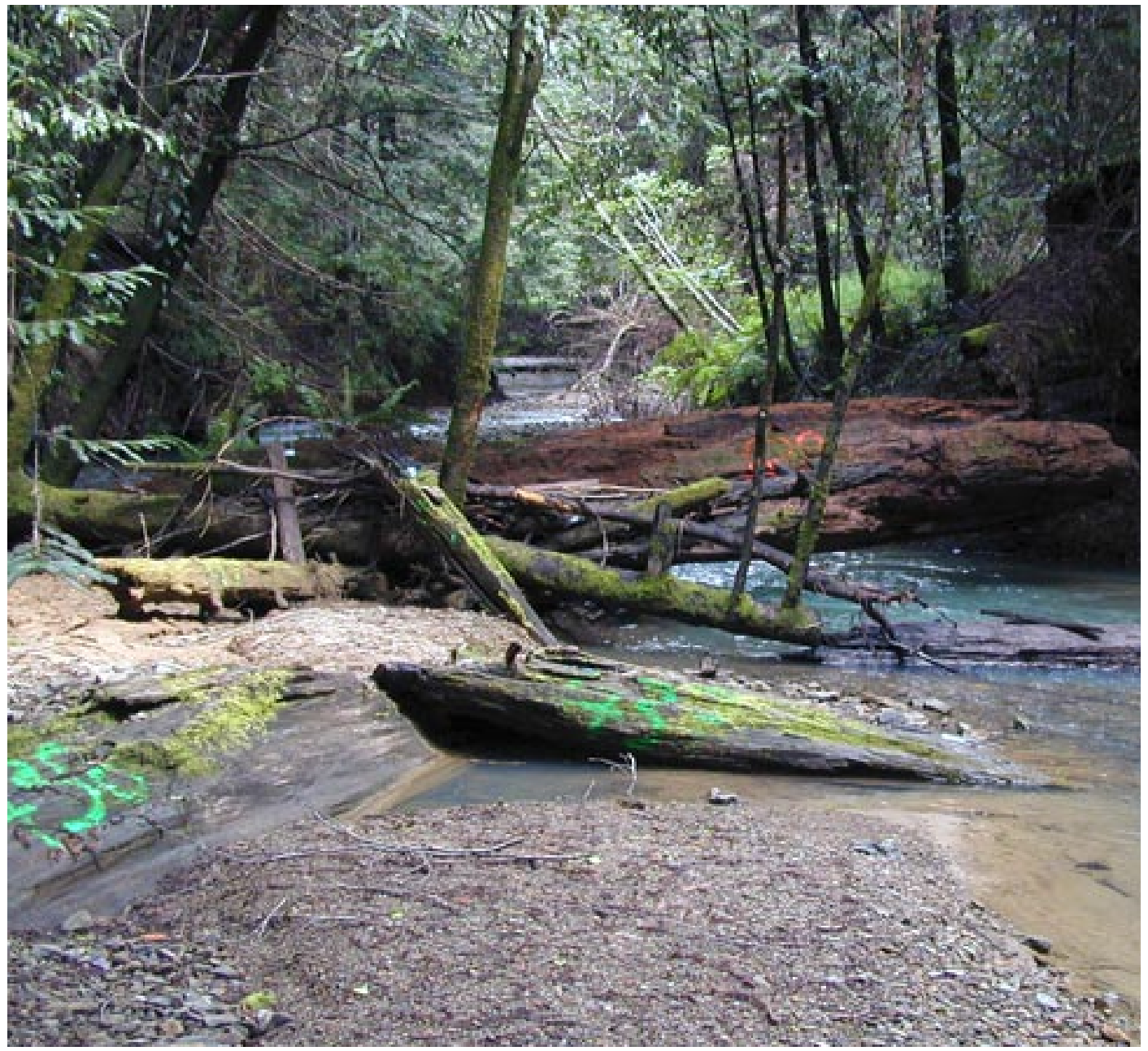




\section{RESOURCES}

Several programs in California provide cost sharing for projects aimed at watershed or stream restoration. On the coast, these include the Fisheries Habitat Restoration Grant program administered by DFG. There and elsewhere, funding is also available from other agencies such as the Natural Resources Conservation Service (NRCS) and CAL FIRE. To find out about these and other programs, contact your local University of California Cooperative Extension, DFG, or CAL FIRE offices.

\section{FOR FURTHER INFORMATION}

To order or obtain printed ANR publications and other products, visit the ANR Communication Services online catalog at http://anrcatalog.ucdavis.edu. You can also place orders by mail, phone, or FAX, or request a printed catalog of our products from:

University of California

Agriculture and Natural Resources

Communication Services

6701 San Pablo Avenue, 2nd Floor

Oakland, California 94608-1239

Telephone: (800) 994-8849 or (510) 642-2431

FAX: (510) 643-5470

E-mail inquiries: danrcs@ucdavis.edu

An electronic version of this publication is available on the ANR Communication Services Web site at http://anrcatalog.ucdavis.edu.

Publication 8239

ISBN-13: 978-1-60107-459-1

(C) 2007 by the Regents of the University of California, Division of Agriculture and Natural Resources. All rights reserved.

The University of California prohibits discrimination or harassment of any person on the basis of race, color, national origin, religion, sex, gender identity, pregnancy (including childbirth, and medical conditions related to pregnancy or childbirth), physical or mental disability, medical condition (cancer-related or genetic characteristics), ancestry, marital status, age, sexual orientation, citizenship, or status as a covered veteran (covered veterans are special disabled veterans, recently separated veterans, Vietnam era veterans, or any other veterans who served on active duty during a war or in a campaign or expedition for which a campaign badge has been authorized) in any of its programs or activities. University policy is intended to be consistent with the provisions of applicable State and Federal laws.

Inquiries regarding the University's nondiscrimination policies may be directed to the Affirmative Action/Staff Personnel Services Director, University of California, Agriculture and Natural Resources, 300 Lakeside Drive, 6th Floor, Oakland, CA 94612-3550 (510) 987-0096. For a free catalog of other publications, call (800) 994-8849. For help downloading this publication, call (530) 297-4445.

This publication has been anonymously peer reviewed for technical accuracy by University of California scientists and other qualified professionals. This review process was managed by the ANR Associate Editor for Natural Resources.

pr-12/07-SB/RW 